\title{
POLA KOMUNIKASI PENGGUNA APLIKASI CHATTING (STUDI PADA KOMUNITAS ANDROID MAKASSAR)
}

\author{
Rahmita Saleh \\ Suwardi Thahir \\ Dosen pada Program Studi Ilmu Komunikasi, Universitas Fajar Makassar \\ mita.saleh@gmail.com \\ suwardithahir17@gmail.com
}

\begin{abstract}
Abstrak
Kehadiran internet dan sistem operasi Android menjadikan komunikasi semakin mudah dilakukan tanpa ada hambatan jarak dan waktu. Perubahan cara berkomunikasi, gaya hidup dan pemenuhan kebutuhan manusia adalah beberapa dampak dari hadirnya inovasi ini. Salah satu perubahan cara berkomunikasi yang paling berpengaruh adalah perilaku percakapan sehari-hari yang didominasi oleh penggunaan aplikasi menggunakan perangkat mobile. Penelitian ini bertujuan untuk mengetahui pola komunikasi pengguna aplikasi chatting dengan memfokuskan penelitian pada kelompok sosial Komunitas Android Makassar yang merupakan kelompok yang ikut mempopulerkan penggunaan perangkat berbasis sistem operasi Android di Makassar. Metode penelitian yang digunakan adalah kualitatif dengan pendekatan Etnografi Komunikasi untuk menggambarkan secara detail pola komunikasi melalui hubungan antara komponenkomponen komunikasi dalam setting tertentu. Hasil penelitian menunjukkan bahwa Pola komunikasi kelompok Komunitas Android Makassar dalam berkomunikasi menggunakan aplikasi chatting cenderung bersifat massa namun terdapat dua perbedaan yaitu pada umpan balik dan model penyebaran pesan. Selain itu, bentuk komunikasi pengguna aplikasi chatting berupa dialog satu-ke-banyak dan terjadi secara asinkron yang berarti bahwa peserta tidak berpotensi untuk saling berinteraksi secara nyata karena berlangsung menggunakan perantara berupa perangkat mobile.
\end{abstract}

Kata kunci : Pola Komunikasi, Aplikasi chatting, Komunitas Android Makassar 


\section{PENDAHULUAN}

\subsection{Latar Belakang Masalah}

Seiring dengan pesatnya perkembangan zaman dan motivasi masyarakat untuk memenuhi kebutuhan komunikasinya, maka hadirnya berbagai macam teknologi di bidang komunikasi menjadi alat yang dapat digunakan untuk memenuhi kebutuhan dan kepuasan manusia dengan cepat dan mudah. Perkembangan ini menyebabkan aktivitas berkomunikasi manusia saat ini didominasi oleh teknologi dan secara tidak langsung menimbulkan perubahan dalam kehidupan sosial dan budaya manusia.

Perkembangan ini salah satunya dipengaruhi oleh hadirnya inovasi sistem operasi berbasis Android yang mengandalkan koneksi internet dalam melakukan komunikasi (Kusumaningati, 2012). Setelah hadirnya Android, pengalaman berkomunikasi tidak hanya menggunakan fungsi telepon reguler dan SMS saja. Berkomunikasi telah menggunakan fungsi internet sehingga dapat dilakukan melalui berbagai macam cara bahkan hingga lintas benua, diantaranya melalui aplikasi percakapan, bertelepon menggunakan jaringan internet, melakukan kontak seperti layaknya walkie talkie, berkomunikasi melalui email, mencari informasi melalui website, dan sebagainya (E.W, 2012).

Kehadiran internet menjadikan komunikasi semakin mudah dilakukan tanpa ada hambatan jarak dan waktu lagi. Perubahan cara berkomunikasi, gaya hidup dan pemenuhan kebutuhan manusia adalah beberapa dampak dari hadirnya inovasi ini. Salah satu perubahan cara berkomunikasi yang paling berpengaruh adalah perilaku percakapan sehari-hari yang didominasi oleh penggunaan aplikasi chatting atau dikenal juga dengan istilah instant messaging.

Percakapan menggunakan aplikasi chatting khususnya melalui perangkat mobile merupakan aktivitas berkomunikasi yang paling populer digunakan oleh pengguna internet di Indonesia saat ini. Berdasarkan survey APJII (Aliansi Penyedia Jasa Internet di Indonesia) pada tahun 2017 , sebanyak $89,35 \%$ dari total 143,26 juta pengguna internet di Indonesia merupakan pengakses layanan chatting.

Data ini menunjukkan bahwa tren instant messaging atau percakapan singkat menggunakan aplikasi chatting sudah sangat populer digunakan masyarakat Indonesia. Pergeseran pola komunikasi dari bentuk komunikasi langsung, tatap muka atau nyata mulai berpindah ke pola komunikasi secara virtual melalui penggunaan perantara perangkat mobile dengan teks menjadi bahasa baru yang digunakan sehari-hari. 
Hal ini berdampak pada perilaku pengguna internet yang kini lebih aktif berkomunikasi dengan orang-orang dalam daftar kontaknya daripada berkomunikasi di dunia nyata.

Perubahan pola komunikasi ini menarik untuk dikaji lebih dalam untuk mendapatkan deskripsi pola-pola komunikasi yang muncul. Dalam kajian ilmu komunikasi, pendekatan untuk mengkaji pola atau perilaku komunikasi dikenal dengan istilah etnografi komunikasi.

Etnografi komunikasi merupakan sebuah metode untuk menafsirkan suatu budaya atau sistem kelompok sosial dengan menguji kelompok tersebut dan mempelajari pola perilaku, kebiasaan dan cara hidup, arti atau makna dari setiap perilaku, serta bahasa dan interaksi dalam kelompok tersebut.

Untuk mendapatkan deskripsi pola komunikasi pengguna aplikasi chatting, kelompok sosial yang akan diteliti adalah Komunitas Android Makassar, yang didasarkan pada terbentuknya kelompok sosial tersebut seiring dengan mulainya digunakan sistem operasi Android di Indonesia. Penelitian pola komunikasi pengguna aplikasi chatting dengan menggunakan pendekatan etnografi komunikasi juga dapat diterapkan pada kelompok sosial lainnya.

\subsection{Rumusan Masalah}

Berdasarkan latar belakang masalah di atas, rumusan masalah dalam penelitian ini adalah : bagaimana pola komunikasi kelompok Komunitas Android Makassar dalam berkomunikasi menggunakan aplikasi chatting?

\section{TINJAUAN PUSTAKA}

\subsection{Komunikasi Berperantarakan Komputer-Internet}

Komunikasi Berperantarakan Komputer-Internet (KBKI) di dunia siber menurut Herimansyah (badanbahasa.kemdikbud.go.id) dapat dikatakan sebagai genre baru dalam berkomunikasi. Dalam tinjauan yang menyeluruh, David Crystal (2001) dalam Herimansyah memperlihatkan bahwa percakapan di internet (yang ditemukan di dalam e-mail, chatting, dan MUD [multi user dungeon atau multi user dimension]) lebih menyerupai bahasa tulisan daripada bahasa ucapan dan menyebutnya sebagai "netspeak" yang merupakan variasi bahasa baru.

Komunikasi di dunia siber biasanya merupakan bentuk komunikasi dialogis, artinya, materi yang ditayangkan ke dalam world wide web dapat dilihat oleh pengguna internet lainnya 
dan dimungkinkan juga untuk memberikan tanggapan. KBKI dapat diorganisasikan dengan mempertimbangkan dua hal yaitu, (1) ranah yang direpresentasikan dalam dialog atau monolog, (2) apakah komunikasi yang terjadi itu asinkron (peserta tidak berpotensi untuk saling berinteraksi secara waktu nyata) atau sinkron (komunikasi waktu nyata).

Berdasarkan pertimbangan di atas, KBKI dapat dikelompokkan menjadi (1) dialog satuke-satu (misalnya, e-mail dan SMS), (2) dialog satu-ke-banyak (misalnya, mailing list, MUD, MOO [MUDs object oriented] dan chatting), (3) situs web, dan (4) jejaring sosial (facebook, myspace, twitter dan sebagainya).

Setelah internet popular, bahasa Indonesia mengalami berbagai "penyesuaian" atau evolusi. Penggunaan bahasa Indonesia di dalam KBKI cenderung tidak mengikuti aturan tata tulis dan tata bahasa baku karena banyak memuat akronim, simbol (emoticon), serta kalimat dan diksinya dibuat singkat. Selain itu, akronim bahasa Inggris dan emoticon, baik yang menggunakan kombinasi tanda baca maupun grafik, juga banyak digunakan dalam KBKI. Ditambah dengan beberapa kata dari bahasa daerah dan juga bahasa Inggris serta penggunaan tanda baca yang lebih menjadikan komunikasi di dalamnya menjadi ekspresif.

Pemakaian bahasa di dalam KBKI yang tidak mengikuti tatanan bahasa baku, hal itu dipandang oleh beberapa ahli bahasa dapat merusak bahasa yang bersangkutan apabila nantinya pemakai terbiasa menggunakan bahasa tersebut dan menerapkannya di dalam bahasa lisan atau tulisan formal. Namun, beberapa pengamat bahasa menganggap bahwa hal itu merupakan suatu evolusi atau bahkan revolusi bahasa yang terjadi di dalam media baru yang berbeda dari bahasa ucapan dan bahasa tulisan.

\subsection{Berkomunikasi Melalui Android}

Android merupakan sebuah Operating System (OS) atau Sistem Operasi berbasis Linux yang diciptakan untuk telepon seluler. Android dikembangkan oleh Android Inc, perusahaan pembuat piranti lunak telepon selular. Perilisan Android pertama kali dilakukan pada 5 November 2007 dan telepon selular pertama yang memakai OS Android adalah HTC Dream yang dirilis pada 22 Oktober 2008 (Kusumaningati, 2012: 3). Keunggulan Android dibandingkan OS lainnya adalah bersifat open source sehingga bisa digunakan dan dikembangkan oleh siapa saja, di desain untuk koneksi internet maksimal, memiliki manajemen aplikasi otomatis, kualitas gambar dan suara yang baik, serta memiliki fleksibilitas pada berbagai macam hardware. 
OS Android menciptakan pengalaman baru dalam berkomunikasi melalui berbagai aplikasi. Jika selama ini untuk berkomunikasi menggunakan telepon selular fungsi yang digunakan adalah telepon dan SMS, dengan pengembangan yang dilakukan oleh Android, pengalaman lain dalam berkomunikasi tercipta melalui aplikasi dengan menggunakan jaringan internet. Pengalaman tersebut antara lain, chatting dalam berbagai cara, bertelepon melalui jaringan internet secara gratis, melakukan kontak seperti layaknya walkie talkie, berkomunikasi melalui email, dan mencari informasi dengan website yang dapat dilakukan kapan saja dan dimana saja selama terhubung dengan jaringan internet.

Beberapa aplikasi berkomunikasi yang populer setelah hadirnya OS Android (E.W, 2012 : 2) adalah : (1) Instant Messenger atau chatting (WhatsApp Messenger, eBuddy, AndroIRC, dan sebagainya), (2) Telepon gratis (Viber, Nimbuzz, LINE dan sebagainya), (3) Push-To-Talk atau walkie talkie, (4) Email, dan (5) Browsing.

\subsection{Etnografi Komunikasi}

Etnografi komunikasi merupakan metode etnografi yang diterapkan untuk melihat polapola komunikasi kelompok sosial. Kajian etnografi komunikasi menawarkan pengetahuan yang mendalam tentang pengalaman individu dan kelompok.

Tradisi penelitian ini ditemukan oleh seorang antropolog bernama Dell Hymes yang mengusulkan bahwa linguistik formal saja tidak cukup untuk membongkar sebuah pemahaman bahasa secara lengkap karena hal ini mengabaikan variabel yang sangat berguna dimana bahasa digunakan dalam komunikasi sehari-hari. Menurut Hymes, budaya komunikasi memiliki cara yang berbeda, tetapi semua bentuk komunikasi membutuhkan kode bersama, pelaku komunikasi yang tahu dan menggunakan kode, sebuah alat, keadaan, bentuk pesan, topik, dan sebuah peristiwa yang diciptakan dengan penyebaran pesan (Littlejohn, 2011:460-461).

Etnografi komunikasi secara ilmiah membahas bahasa, komunikasi dan kebudayaan dalam satu konteks dan pada satu kelompok masyarakat tertentu (Kuswarno, 2011:29). Secara spesifik, etnografi komunikasi akan menghasilkan hipotesis mengenai berbagai cara, bagaimana fenomena sosiokultural dalam masyarakat itu berhubungan dengan pola-pola komunikasi atau cara-cara berbicara. Adapun fokus kajian dari etnografi komunikasi adalah perilaku-perilaku komunikatif suatu mayarakat. 
Hymes mengemukakan tahapan-tahapan untuk melakukan penelitian etnografi komunikasi dalam suatu masyarakat tutur (speech community) sebagai berikut (Kuswarno, 2011:37) :

Sebagai langkah awal untuk mendeskripsikan dan menganalisis pola komunikasi yang ada dalam suatu masyarakat, adalah dengan mengidentifikasi peristiwa-peristiwa komunikasi yang terjadi secara berulang. Langkah selanjutnya menginventarisasi komponen yang membangun peristiwa komunikasi, kemudian menemukan hubungan antar komponen tersebut.

Definisi istilah dalam tahapan tersebut dapat dijelaskan sebagai berikut :

1. Peristiwa komunikasi yang terjadi secara berulang (recurrent events) dalam etnografi komunikasi adalah peristiwa-peristiwa komunikasi yang signifikan, dan menjadi ciri khas dari perilaku komunikasi suatu kelompok masyarakat.

2. Peristiwa komunikasi menurut etnografi komunikasi adalah keseluruhan perangkat komponen yang utuh, yang dimulai dengan tujuan utama komunikasi, topik umum yang sama, dan melibatkan partisipan yang secara umum menggunakan varietas bahasa yang sama, mempertahankan tone yang sama dan kaidah-kaidah yang sama untuk berinteraksi, dan dalam setting yang sama. Sebuah peristiwa berakhir bila ada perubahan dalam batasanbatasannya, misalnya ketika terdapat keheningan, atau perubahan posisi tubuh partisipan komunikasi.

3. Komponen komunikasi menurut etnografi komunikasi adalah unit-unit komunikasi yang menunjang terjadinya suatu peristiwa komunikasi yang terdiri dari tipe peristiwa, topik, tujuan, setting, partisipan, bentuk pesan, isi pesan, urutan tindakan, kaidah interaksi dan norma interaksi.

4. Hubungan antar komponen yang dimaksud adalah bagaimana setiap komponen komunikasi saling bekerja sama untuk menciptakan perilaku komunikasi yang khas dari kelompok masyarakat tersebut. 


\section{METODE PENELITIAN}

\subsection{Tahapan Penelitian}

Metode etnografi komunikasi merupakan metode etnografi yang diterapkan untuk melihat pola-pola komunikasi kelompok sosial. Untuk mencapai hal tersebut, penelitian ini perlu dilakukan secara in-depth studies pada komunitas yang akan diteliti. Seperti yang dinyatakan oleh Kriyantono (2010:67), peneliti biasanya terjun langsung dalam waktu yang lama dan bergaul di tengah-tengah masyarakat yang ditelitinya.

Tahapan-tahapan penelitian yang dilakukan untuk menggambarkan pola komunikasi pengguna aplikasi chatting adalah (Kuswarno, 2011:37) :

(1) Mengidentifikasi peristiwa-peristiwa komunikasi yang terjadi secara berulang (reccurent events) dalam aktivitas komunikasi menggunakan aplikasi chatting yang dilakukan oleh Komunitas Android Makassar

(2) Menginventarisir komponen komunikasi yang membangun peristiwa komunikasi yang berulang tersebut

(3) Menemukan hubungan antarkomponen komunikasi yang membangun peristiwa komunikasi tersebut untuk dapat mengetahui pola komunikasinya (communication pattering)

\subsection{Lokasi Penelitian}

Penelitian ini berlokasi di Makassar yang merupakan lokasi dari keberadaan objek yang dikaji yaitu Komunitas Android Makassar.

\subsection{Teknik Pengumpulan Data}

Penelitian etnografi komunikasi adalah penelitian yang menyeluruh atau holistic, terutama untuk menggali dunia konseptual objek penelitian dari aspek pembicara asli (native speaker). Oleh karena itu teknik utama pengumpulan data dalam penelitian ini menggunakan teknik observasi, wawancara dan analisis dokumen.

Observasi dan wawancara merupakan metode pengumpulan data primer. Observasi dilakukan terhadap percakapan-percakapan yang dilakukan anggota Komunitas Android Makassar menggunakan aplikasi chatting. Wawancara dilakukan terhadap ketua Komunitas Android Makassar sebagai gatekeeper yang merupakan seseorang yang diakui sebagai bagian dari kelompok yang diteliti serta menjadi akses pertama peneliti untuk masuk ke dalam 
lingkungan kelompok yang diteliti (gaining access). Sementara analisis dokumen merupakan metode sekunder, yang bertujuan untuk mendapatkan data tertulis atau dokumen pendukung yang dapat menghasilkan informasi mengenai objek yang diteliti.

\subsection{Analisis Data}

Analisis data yang dilakukan menggunakan teknik analisis yang dikemukakan oleh Creswell (Kuswarno, 2011:68) yang meliputi :

(1) Deskripsi. Pada tahap ini, peneliti mempresentasikan hasil penelitiannya dengan menggambarkan secara detail objek yang diteliti dengan gaya penyampaian yang kronologis atau berurutan dan membangun cerita yang lengkap.

(2) Analisis. Pada tahap ini, peneliti mengemukakan beberapa data akurat mengenai objek penelitian. Penjelasan pola-pola atau regulatitas dari perilaku yang diamati juga termasuk dalam tahap ini. Analisis juga dapat dilakukan dengan membandingkan objek yang diteliti dengan objek lain, mengevaluasi objek dengan nilai-nilai umum yang berlaku, atau membangun hubungan antara objek penelitian dengan lingkungan yang lebih besar.

(3) Interpretasi. Interpretasi adalah tahap akhir analisis data dalam penelitian ini. Dalam hal ini, peneliti membuat kesimpulan dari penelitian yang telah dilakukan dengan menggunakan kata orang pertama dalam penjelasannya, untuk menegaskan bahwa apa yang dikemukakan adalah murni hasil interpretasi peneliti.

\section{HASIL PENELITIAN DAN PEMBAHASAN}

\subsection{Hasil Penelitian}

Hasil yang diperoleh dari penelitian terhadap pola komunikasi kelompok sosial Komunitas Android Makassar dalam menggunakan aplikasi chatting dapat dijelaskan dalam tahapan-tahapan berikut :

\section{(1) Peristiwa komunikasi yang terjadi secara berulang}

Penelitian ini mengkaji perilaku komunikasi anggota Komunitas Andriod Makassar dalam berkomunikasi menggunakan aplikasi chatting. Peristiwa-peristiwa komunikasi yang terjadi secara berulang (reccurent events) dalam aktivitas komunikasinya adalah percakapan menggunakan aplikasi Kakao Talk dalam grup bernama Android Makassar. Tema yang menjadi perbincangan adalah produk baru atau perangkat-perangkat elektronik tambahan/pendukung 
perangkat berbasis sistem operasi Android. Istilah yang mereka gunakan untuk menggambarkan perangkat elektronik tersebut adalah racun. Berikut ini merupakan salah satu bentuk percakapan dalam akun grup Android Makassar :
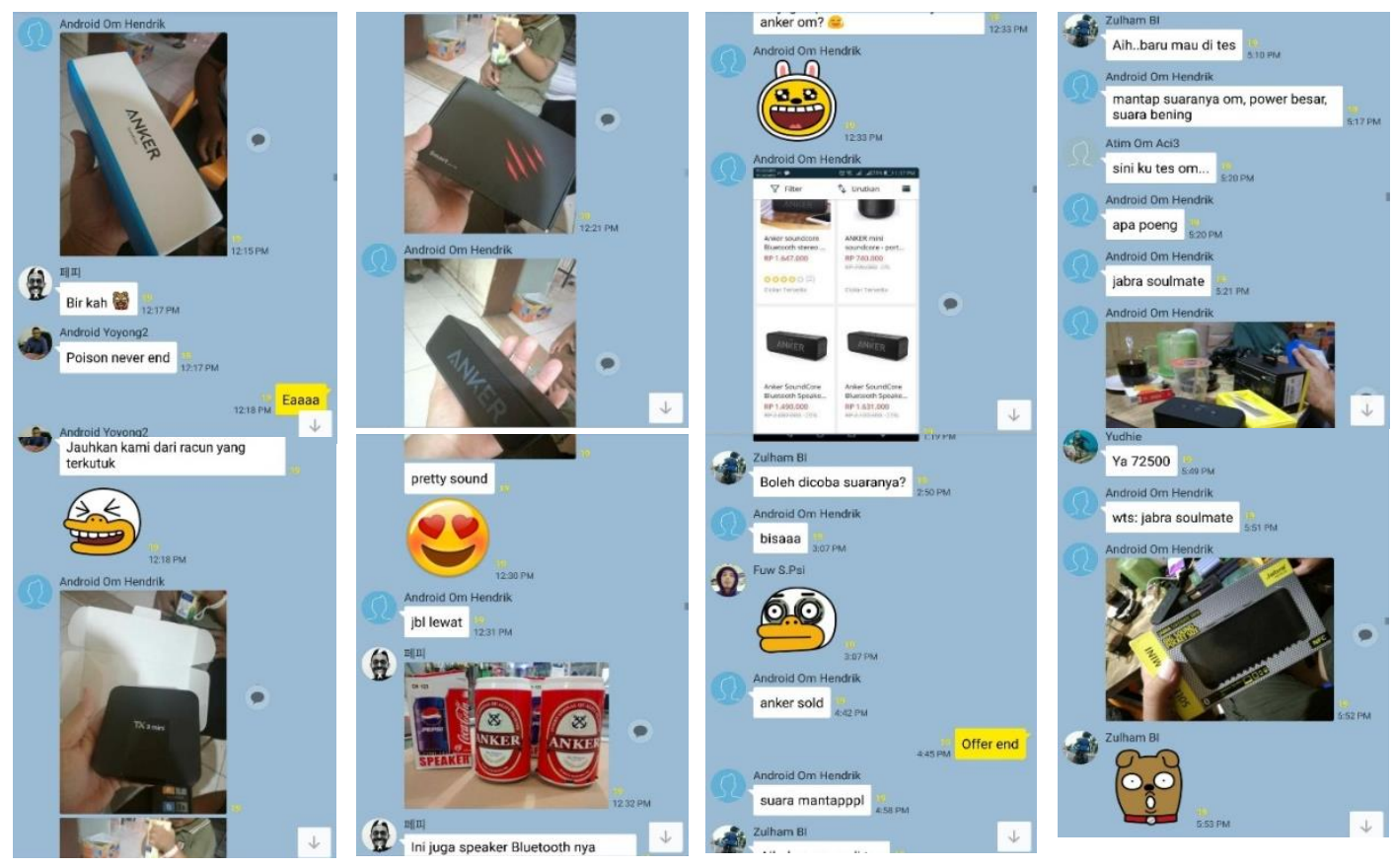

Gambar 1. Percakapan akun grup Android Makassar pada tanggal 30 November 2017 pada aplikasi chatting Kakao Talk

(Sumber : Ketua Komunitas Android Makassar, Muhammad Resha)

\section{(2) Komponen komunikasi}

Komponen-komponen yang membangun peristiwa komunikasi yang berulang tersebut (berdasarkan Gambar 1) :

a. Aktivitas komunikasi dilakukan menggunakan aplikasi chatting Kakao Talk dalam akun grup bernama Android Makassar yang berlangsung pada tanggal 30 November 2017 pukul 12.15 PM hingga 5.53 PM

b. Percakapan tersebut memperbincangan fitur pendukung audio pada perangkat telekomunikasi mobile berbasis Android.

c. Percakapan diawali dengan postingan atau kiriman sebuah gambar/foto yang menunjukkan sebuah benda dengan tulisan ANKER SoundCare dan diperbincangkan oleh anggota lainnya. 
d. Percakapan ini dilakukan melalui sebuah perangkat telekomunikasi yang telah memiliki aplikasi Kakao Talk. Karena percakapan berlangsung dalam sebuah aplikasi, maka percakapan hanya akan dilihat, ditanggapi dan diketahui oleh anggota komunitas yang telah terdaftar dalam akun grup bernama Android Makassar. Pada umumnya, bentuk pesan yang dikirim melalui aplikasi akan disesuaikan dengan fasilitas yang tersedia. Fasilitas yang disediakan berupa saluran vokal dan nonvokal. Saluran vokal berupa teks (pesan yang menggunakan kata-kata) dan audio (suara yang direkam). Sementara saluran nonvokal berupa fasilitas multimedia lainnya berupa pesan visual (pesan yang menggunakan gambar atau emoticon) dan audio visual (video).

e. Partisipan yang terlibat dalam percakapan berjumlah delapan orang yang didominasi oleh anggota berjenis kelamin laki-laki dengan rentang usia antara 29 hingga 43 tahun.

f. Pesan disampaikan dalam dua format, yaitu teks dan visual. Pesan teks berupa pesan yang menggunakan kata-kata dan visual berupa pesan yang menggunakan foto atau emoticon (bentuk tipografi yang merepresentasikan ekspresi wajah maupun emosi). Dua format ini merupakan keunikan perilaku komunikasi Komunitas Android Makassar karena keduanya mendasari keseluruhan perilaku komunikasi mereka. Pesan teks yang dikomunikasikan disampaikan dalam bahasa Indonesia dan bahasa Inggris, namun penyampiannya sesuai dengan kebiasaan berkomunikasi yang sering dilakukan masyarakat Makassar.

g. Pesan yang disampaikan berupa informasi sebuah perangkat yang menarik ketertarikan anggota lainnya (partisipan) untuk mengetahui kemampuan dan harga perangkat tersebut.

h. Percakapan dimulai oleh sebuah akun yang memberi informasi sebuah perangkat yang ditanggapi oleh tujuh partisipan lainnya. Dalam percakapan tersebut, seluruh partisipan berkomunikasi dengan mengirimkan pesan pada kotak percakapan yang dilakukan secara bebas dan acak kemudian masing-masing di jawab oleh pembuka percakapn dan beberapa partisipan lainnya yang memiliki ketertarikan terhadap pesan yang dikirimkan.

i. Semua peristiwa tutur berlangsung dalam kotak percakapan Kakao Talk yang dapat dilihat oleh 52 anggota (akun) yang terdaftar dalam grup Android Makassar. Semua akun memiliki kesempatan yang sama untuk terlibat dalam percakapan (sebagai partisipan), mereka dapat memilih untuk terlibat secara langsung ataupun tidak. Seluruh partisipan yang berinteraksi dalam percakapan menunjukkan adanya saling pemahaman terhadap 
pesan yang dikirim, bahkan meskipun pesan hanya berupa sebuah gambar ataupun emoticon.

j. Peristiwa tutur yang berlangsung menunjukkan kesan yang santai dengan sering diselingi emoticon yang mewakili ekspresi lucu atau tertawa.

\section{(3) Hubungan antarkomponen}

Yang menjadi dasar pembentukan pola komunikasi (communication pattering) adalah peristiwa komunikasi berdasarkan komponen komunikasi di atas. Dari komponen komunikasi tersebut, pola komunikasi yang muncul adalah pola yang memiliki ciri komunikasi massa, yaitu sifat pesannya terbuka dengan khalayak yang variatif, penyebarannya cepat, serempak dan luas yang mampu mengatasi jarak dan waktu (Cangara, 2011:37).

Pesan-pesan yang dikirimkan oleh partisipan memiliki dua bentuk/format, yaitu teks dan multimedia. Pesan berupa teks atau kata-kata beberapa diantaranya adalah Bir kah, poison never end, jauhkan kami dari racun yang terkutuk, dan apa poeng. Sementara pesan berupa multimedia berbentuk gambar/foto dan emoticon, seperti pada Gambar 1 di atas.

Bahasa yang digunakan dalam percakapan bervariasi antara Bahasa Indonesia, Bahasa Inggris, Bahasa Indonesia dengan aksen Makassar, serta menggunakan gabungan kata-kata dengan emoticon. Namun, bahasa tersebut dapat dipahami oleh para partisipan yang ditunjukkan dengan adanya tanggapan atau balasan dari setiap pesan yang dikirim.

\subsection{Pembahasan}

Analisis terhadap aktivitas komunikasi Komunitas Android Makassar dalam berkomunikasi menggunakan aplikasi chatting sebagai berikut :

Kelompok sosial Komunitas Android Makassar mulai berdiri pada tahun 2010 pada saat sistem operasi Andorid belum terlalu popular di Indonesia. Pada tahun 2013 ketika Android mulai populer di Indonesia khususnya Makassar, komunitas ini memiliki banyak kegiatan dalam memperkenalkan Android, diantaranya mengikuti pameran dan menjadi narasumber dalam seminar-seminar Teknologi Informasi yang berhubungan dengan Android.

Komunitas ini awalnya didirikan oleh empat orang inisiator kemudian berkembang hingga memiliki puluhan ribu pengikut pada akun grup Facebook Android Makassar. Setelah sistem operasi Android semakin populer di masyarakat, aktivitas komunitas ini mulai berkurang, para anggota mulai menyebar di berbagai Kota di Indonesia dan beralih topik perbincangan. 
Untuk terus berkomunikasi dengan sesama anggota valid yang pada tahun 2017 berjumlah 52 orang, mereka terus menjalin komunikasi menggunakan aplikasi chatting Kakao Talk dengan perbincangan yang lebih difokuskan pada perangkat-perangkat pendukung atau perkembangan terkini sistem operasi Android. Pada aplikasi tersebut, mereka tergabung dalam sebuah akun grup bernama Android Makassar yang memiliki 52 akun dari 52 anggota.

Salah satu perbincangan kelompok tersebut adalah mengenai sebuah perangkat pendukung audio untuk perangkat mobile yang dapat disambungkan menggunakan Bluetooth (Gambar. 1). Perbincangan dilakukan oleh delapan orang partisipan, yaitu delapan orang anggota komunitas dalam grup dari total anggota sebanyak 52. Berdasarkan percakapan yang berlangsung pada pukul 12.15 PM hingga 5.53 PM, terdapat 32 postingan atau kiriman pesan yang terdiri atas percakapan berbentuk kata-kata, gabungan kata dan emoticon, emoticon dan gambar.

Berdasarkan ciri-ciri pola komunikasi yang digunakan pada percakapan dalam aplikasi chatting tersebut, maka pola komunikasi yang digunakan Komunitas Android Makassar lebih cenderung bersifat pola komunikasi massa. Pola komunikasi ini berupa komunikasi yang ditujukan kepada sejumlah besar orang yang tersebar di banyak tempat, pesan-pesannya bersifat umum dan mengandalkan peralatan modern untuk menyebarkan pesan secara cepat.

Meskipun pola komunikasi pada aplikasi chatting bersifat massa, namun pada kasus di atas terdapat dua perbedaan dengan pola komunikasi massa pada umumnya. Pertama adalah umpan balik, komunikasi massa umpan baliknya dua arah atau bisa dilangsungkan secara interaktif, sementara komunikasi menggunakan aplikasi chatting umpan baliknya bisa dilakukan dengan banyak orang dan banyak topik (multiuser and topic). Kedua adalah pesan, dalam komunikasi massa pesan bersifat publik sehingga bisa didapatkan oleh banyak orang yang sifatnya heterogen, sementara pada aplikasi chatting pesan disebarkan secara serentak untuk sekelompok orang tertentu yang tergabung dalam akun grup pada sebuah aplikasi.

Pada pola komunikasi yang terbentuk, bentuk kode dan bahasa kelompok Komunitas Android Makassar dalam tinjauan badan bahasa merupakan bentuk komunikasi yang dikenal dengan istilah KBKI (Komunikasi Berperantarakan Komputer-Internet) yang merupakan genre baru dalam berkomunikasi. Komunikasinya berupa dialog satu-ke-banyak dan terjadi secara asinkron dimana peserta tidak berpotensi untuk saling berinteraksi secara waktu nyata karena berlangsung menggunakan perantara perangkat mobile. 
Gaya bahasa yang dipadu dengan emoticon, baik yang konvensional maupun yang tidak, menambah hidupnya percakapan sehingga dapat mewakili percakapan langsung atau tatap muka. Penggunaan emoticon menjadi sarana KBKI yang banyak digunakan dan dianggap lebih efektif untuk mengekspresikan berbagai ungkapan. Emoticon dibentuk dengan mengombinasikan tanda baca (kadang-kadang dengan karakter dan angka) untuk merepresentasikan emosi atau nuansa semantik, seperti kegembiraan, kesedihan, atau perasaan.

Percakapan pada aplikasi chatting yang banyak memuat akronim, simbol (emoticon), serta kalimat dan diksinya dibuat bervariasi dan singkat menjadikan KBKI cenderung tidak mengikuti aturan tata tulis dan tata bahasa baku. 


\section{KESIMPULAN}

Pola komunikasi kelompok Komunitas Android Makassar dalam berkomunikasi menggunakan aplikasi chatting, berdasarkan ciri-ciri yang digunakan lebih cenderung bersifat massa. Ciri-ciri tersebut adalah sifat pesannya terbuka dengan khalayak yang variatif, penyebarannya cepat dengan mengandalkan peralatan modern, serta serempak dan luas yang mampu mengatasi jarak dan waktu. Namun terdapat perbedaan pada aplikasi chatting, yaitu pada umpan balik yang bisa dilakukan dengan banyak orang dan banyak topik (multiuser and topic) dan pesan yang disebarkan secara serentak hanya untuk sekelompok orang tertentu yang tergabung dalam akun grup pada sebuah aplikasi chatting. Selain itu, bentuk komunikasi pengguna aplikasi chatting berupa dialog satu-ke-banyak dan terjadi secara asinkron dimana peserta tidak berpotensi untuk saling berinteraksi secara waktu nyata karena berlangsung menggunakan perantara perangkat mobile. 


\section{DAFTAR PUSTAKA}

Cangara, Hafied. 2011. Pengantar Ilmu Komunikasi. Jakarta : Rajawali Pers

E.W, Wishnu. 2012. Aplikasi Chatting untuk Andorid. Jakarta : Elex Media Komputindo

Herimansyah, Ganjar. Bahasa Indonesia di Dunia Siber : Komunikasi Berperantarakan Komputer-Internet. (Online).

(http://badanbahasa.kemdikbud.go.id/lamanbahasa/content/bahasa-indonesia-di-dunia-siberkomunikasi-berperantarakan-komputer-internet) diakses pada 24 Mei 2018 pukul 14.00 wita

Kriyantono, Rachmat. 2010. Teknik Praktis Riset Komunikasi : Disertai Contoh Praktis Riset Media, Public Relations, Advertising, Komunikasi Organisasi, Komunikasi Pemasaran. Jakarta : Kencana

Kusumaningati, Imam FR. 2012. Ngandroid : Hidup Menjadi Mudah dan Menyenangkan dengan Android. Jakarta : Elex Media Komputindo

Kuswarno, Engkus. 2008. Etnografi Komunikasi (Metode Penelitian Komunikasi). Bandung : Widya Padjajaran.

Littlejohn, Stephen W. \& Foss, Karen A. 2011. Theories of Human Communication, $9^{\text {th }}$ Edition. Diterjemahkan oleh Mohammad Yusuf Hamdan. Jakarta : Salemba Humanika.

Survey APJII 2018 